\title{
COVID-19: Molecular and serological detection methods
}

\author{
Ahmed E Dhamad ${ }^{\text {Corresp., } 1,2}$, Muna A Abdal Rhida ${ }^{1,2}$ \\ ${ }^{1}$ Cell and Molecular Biology, University of Arkansas at Fayetteville, Fayetteville, Arkansas, United States \\ 2 Department of Biological Sciences, Wasit University, Kut, Wasit, Iraq \\ Corresponding Author: Ahmed E Dhamad \\ Email address: adhamad@uark.edu
}

Since COVID-19, caused by severe acute respiratory syndrome coronavirus 2 (SARSCoV-2), was declared as a pandemic disease by the World Health Organization (WHO) in early 2020, many countries, organizations, and companies have tried to find the best way to diagnose the virus and contain its spreading. SARS-CoV-2 is a positive-sense single RNA (+ssRNA) coronavirus and mainly spreads through droplets, respiratory secretions, and direct contact. The early detection of the virus plays a central role in lowering COVID19 incidents and mortality rates. Thus, finding a simple, accurate, cheap, and quick detection approach for SARS-CoV-2 at early stage of the viral infection is urgent and at high demand all around the world. The Food and Drug Administration (FDA) and other health agencies have declared Emergency Use Authorization (EUA) to develop diagnostic methods for COVID-19 and fulfill the demand. However, not all developed methods are appropriate and selecting a suitable method is challenging. Among all detection methods, rRT-PCR is the gold standard method. Unlike molecular methods, serological methods lack the ability of early detection with low accuracy. In this review, we summarized the current knowledge about COVID-19 detection methods aiming to highlight the advantages and disadvantages of molecular and serological methods (Fig.1). 
1 COVID-19: Molecular and serological detection methods

2 Ahmed E. Dhamad ${ }^{1,2}$ and Muna A. Abdal Rhida ${ }^{1,2}$

$3 \quad{ }^{1}$ Cell and Molecular Biology, University of Arkansas, Fayetteville, Arkansas, USA

$4 \quad{ }^{2}$ Department of Biological Sciences, Wasit University, Kut, Wasit, Iraq

5

6 Corresponding Author:

7 Ahmed Dhamad 1

81 University of Arkansas, Fayetteville, AR, 72703, USA

9 adhamad@uark.edu 
COVID-19: Molecular and serological detection methods

Ahmed E. Dhamad ${ }^{1,2}$ and Muna A. Abdal Rhida ${ }^{1,2}$

${ }^{1}$ Cell and Molecular Biology, University of Arkansas, Fayetteville, Arkansas, USA

${ }^{2}$ Department of Biological Sciences, Wasit University, Kut, Wasit, Iraq

\section{Abstract}

Since COVID-19, caused by severe acute respiratory syndrome coronavirus 2 (SARS-CoV-2), was declared as a pandemic disease by the World Health Organization (WHO) in early 2020, many countries, organizations, and companies have tried to find the best way to diagnose the virus and contain its spreading. SARS-CoV-2 is a positivesense single RNA (+ssRNA) coronavirus and mainly spreads through droplets, respiratory secretions, and direct contact. The early detection of the virus plays a central role in lowering COVID19 incidents and mortality rates. Thus, finding a simple, accurate, cheap, and quick detection approach for SARS-CoV-2 at the early stage of the viral infection is urgent and at high demand all around the world. The Food and Drug Administration (FDA) and other health agencies have declared Emergency Use Authorization (EUA) to develop diagnostic methods for COVID-19 and fulfill the demand. However, not all developed methods are appropriate and selecting a suitable method is challenging. Among all detection methods, rRT-PCR is the gold standard method. Unlike molecular methods, serological methods lack the ability of early detection with low accuracy. In this review, we summarized the current knowledge about COVID-19 detection methods aiming to highlight the advantages and disadvantages of molecular and serological methods (Fig.1). 
51 Keywords: COVID-19, SARS-CoV-2, rRT-PCR, ID NOW COVID-19, Isothermal

52 Amplification, CRISPR-Cas12, LFA, ELISA

53

54

55

56

57

58

\section{Introduction}

In January 2020, WHO initially named a newly identified $\beta$-coronavirus that caused many pneumonia cases in December 2019 in Wuhan, China as the 2019-novel coronavirus (2019-nCoV) [1, 2]. Eventually, WHO and Coronavirus Study Group (CSG) of International committee officially named the virus as SARS-CoV-2 and the disease as coronavirus disease 2019 (COVID-19) [3]. SARS-CoV-2 is a member of the coronaviruses (CoV) family and it is an enveloped, non-segmented, positive-sense single RNA (+ssRNA) coronavirus [1]. In early 2020, the whole genome sequence of SARS-CoV-2 was revealed which was $29.9 \mathrm{~kb}[4]$ and $96.2 \%$ and $79.5 \%$ identical to a bat CoV RaTG13 and SARS-CoV genome sequences, respectively [2, 5]. CoVs genome includes six to twelve open reading frames (ORFs) [6]. The first and largest ORF (ORF1a/b) occupies approximately two-thirds of the viral RNA $[7,8]$ and the remaining one-third of the genome encodes the four main structural proteins which includes spike $(S)$, envelope $(E)$, membrane $(M)$, and nucleocapsid $(N)$ protein and other accessory proteins [8-11]. The S protein plays a major role in SARS-CoV-2 infectious process and it is a promising target for vaccine and therapeutic development $[12,13]$

COVID-19 virus is a highly contagious and spreads through droplets, respiratory secretions, and direct contact $[14,15]$. Recent studies reported that the virus was isolated from fecal swabs and blood samples of COVID-19 patients $[16,17]$ suggesting that the virus may have different routes to transmit between humans. The number of 
SARS-CoV-2 virus that causes ill to human is not clearly defined yet; however, a large hospitalized cohort $(n=1145)$ was analyzed and the overall mean log10 viral load was $5 \cdot 6$ copies per $\mathrm{mL}$ [18]. Elderly people and whom has chronic underlying diseases, such as but not limited to hypertension [19, 20], diabetes [21, 22], and chronic obstructive pulmonary disease [23], are the most vulnerable [24, 25]. Current studies showed that the median age of COVID-19 patients was $47-59$ years and females were the minority, less than $46 \%$ [26-28]. While children and youth have lower rates of COVID-19 infection compared to elder people [29-31]. The incubation period of the virus is one to fourteen days with 3-7 days being the most [32]

It has been reported that the clinical symptoms of confirmed COVID-19 patients were varied from mild flu-like symptoms to very severe respiratory symptoms and even respiratory and kidney failures and death $[33,34]$. According to WHO and other sources fever, dry cough, and tiredness are the most common symptoms while sore throat, diarrhea, headache, conjunctivitis, rash on skin, and discoloration of fingers or toes are less common symptoms of COVID-19 patients [35-37]. A recent study used an appbased symptom tracker showed that people who had COVID-19 loss of smell and taste and those with a positive test result $(65.03 \%)$ intended to have anosmia higher than those with a negative test result $(21.71 \%)[38,39]$. Although COVID-19 became a pandemic disease, the mortality rate is low (3.4\%) compared to SARS and MERS patients, $9.6 \%$ and $35 \%$ respectively [40].

The first incidents of COVID-19 were diagnosed in Wuhan, China, in December 2019. After a few months, WHO announced COVID-19 as a pandemic disease across the whole world. As of July $2^{\text {ed }} 2020$, a total of $10,716,063$ confirmed cases globally, 
$972,686,587$ confirmed in USA and $8,029,476$ outside of USA, with 516,726 globally

98 deaths were reported by the Coronavirus Resource Center, John Hopkins University

99 [41]. Having a rapid and accurate diagnostic method at early stage of infection can help

100 to contain the pandemic. Thus, many companies and laboratories were given authority

101 under EUA restrictions to develop diagnostic methods. Consequently, hundreds of

102 diagnostic kits based on different methods are available now, but selecting the proper

103 method requires further investigation. In this review, the standard and current molecular

104 and serological detection methods for SARS-CoV-2 will be discussed and highlighted.

105 As of today, among all detection methods rRT-PCR is the gold standard method. Unlike

106 molecular methods, serological methods lack the ability of early detection with low

107 accuracy. This review intends to help health care providers and related branches to

108 choose the appropriate method for battling the COVID-19 pandemic and rise the public

109 knowledge about the methods that could be used to detect the virus.

110

111

112

113

114

115

116

117

118

119

\section{Survey Methodology}

This literature review explored the peer-reviewed and preprint literatures with mainly focusing on COVID-19 disease and its molecular and serological detection methods. We searched the following databases and websites from March to July 2020: Google Scholar, PubMed, bioRxiv, medRxiv, I-TASSER, CDC, WHO, Coronavirus Resource Center (John Hopkins University), Chinese Center for Disease Control and Prevention (CCDC), and National Institute of Infectious Diseases (NIID). And the top keywords that searched were: COVID-19, SARS-CoV-2, coronavirus, genomic RNA, protein structure, ACE2, transmission, symptoms, molecular detection methods, serological detection methods, rRT-PCR, ID NOW COVID-19, isothermal amplification, 
120 121 (RPA), LFA, and ELISA.

CRISPR, SARS-CoV-2 DETECTR, LAMP, recombinase polymerase amplification

\section{Diagnostic methods}

Under the pressure of the pandemic, COVID-19 test demand is sharply increased which pushes a lot of biotech companies/ inventors to produce different kits based on variant approaches to detect SARS-CoV-2. The molecular and serological methods are the main methods to detect the virus.

\section{Molecular methods}

Based on how viral RNA be processed and detected, there are three major molecular methods which are: real-time reverse transcription polymerase chain reaction (rRT-PCR), isothermal amplification, and clustered regularly interspaced short palindromic repeats (CRISPR) based methods. All these methods follow the same protocol that have been recommended by the Centers for Disease Control and Prevention (CDC) for collecting specimens from COVID-19 patients [42].

It is the gold standard and reliable molecular method to diagnose SARS-CoV-2 with high sensitivity (positive agreement) and specificity (negative agreement) [43]. This method has been developed by several laboratories to detect COVID-19 virus [44-46].

138 In this method (Fig. 2B), cDNA is generated from the extracted RNA of COVID-19 virus with specific primers for the following genes 2019nCoV-N1 (N1), 2019nCoV-N2 (N2), and RNAse P (RP; internal control) as recommended by U.S. CDC (Table 1) and other 141 health agencies $[43,47,48]$ (Table S1). The upper respiratory system's swabs are the 
142 main specimens that are used to detect COVID-19 virus; however, serum, ocular

143 secretions, and stool can be used as well [49-51]. If both genes (N1 and N2) were

144 positive, it is considered as a positive sample as shown in Table 2 . The positive result

145 confirms the presence of viral RNA in the specimen, but not necessarily the virus

146 viability [52]. Besides the internal control (RP), there are three controls that must be run

147 to make sure the result is legitimate (Table S2). These controls are 2019-nCoV Positive

148 Control (nCoVPC), No Template Control (NTC), and Human Specimen Control

149 (HSC)[42]. Even though rRT-RPC is the gold standard method and the most widely

150 used for diagnosing COVID-19 virus in clinic and research laboratories, it has some

151 limitations [53]. Beside highly costed, professional skills needed, it is time-consuming

152 (requires 2-5 days from collecting a sample till getting the result) and must be done in a 153 laboratory.

154 Isothermal amplification-based method

155 It is another molecular approach where a nucleic acid is rapidly and specifically 156 amplified by a polymerase with high strand displacement activity (e.g. optimized Bst

157 polymerase) and different sets of primers at constant temperature $\left(60-65^{\circ} \mathrm{C}\right)$ without the 158 need of thermal cycler [54]. ID NOW COVID-19 (Abbott) is a recent example of using 159 isothermal amplification technique to detect COVID-19 virus in clinics. It is molecular 160 point-of-care platform in the United States of America and used under an Emergency 161 Use Authorization (EUA) only to diagnose SARS-CoV-2. In this test a certain region of

162 RdRp gene of SARS-CoV-2 is amplified by specific primers and results are displayed in 163 a short time compared to rRT-PCR (Fig. 2A). It can show a positive result as little as 5 164 minutes and a negative result in 13 minutes. It has a performance of $\geq 94 \%$ sensitivity 
165 and $\geq 98 \%$ specificity compared to lab-based PCR reference tests as it is advertised by

166 the manufacturers [55]. However, Harrington et. al. results that published in a peer-

167 reviewed journal showed that the overall sensitivity and specificity were $74.73 \%$ and

$16899.41 \%$, respectively [56].

169 CRISPR-Cas12 based method

In this method (e.g. SARS-CoV-2 DETECTR), the RNA virus is extracted from a specimen and designated regions of N2, E, RP genes are amplified at $62^{\circ} \mathrm{C}$ for $20 \mathrm{~min}$ by specific primes through Reverse Transcription Loop-mediated Isothermal Amplification (RT-LAMP) approach[57-59]. Then, designed Cas12 gRNAs direct Cas12 protein to specific areas of the above amplified genes where a reporter molecule (a single stranded DNA (ssDNA) probe) is cleaved. This reaction occurs at $37^{\circ} \mathrm{C}$ for $10 \mathrm{~min}$ and the result is visualized by a fluorescent reader or a lateral flow strip (Fig. 2C). Both genes N2 and E must be positive to consider the sample is positive (Table 3).

Broughton et al. showed that SARS-CoV-2 DETECTR was reliable to detect coronavirus in respiratory swab samples with $90 \%$ sensitivity and $100 \%$ specificity[60]. Unlike rRT-PCR, this method is fast ( $<50$ minutes), cheap, and point-of-care test (POCT). It requires less equipment and the result can be visualized by naked eyes. However, it requires troubleshooting and specific design of all enzymes, primers, and reporters that are used in this method. (RPA) [61] has been developed and/or integrated with other methods to detect COVID19 virus. This method does not require thermal cycler and can be used as POCT with

187 low cost and high sensitivity and specificity. The drawback is that it requires several 
188

189

190

191

192

193

194

195

196

197

198

199

200

201

202

203

204

205

206

207

208

209

specific designed primers which could be difficult to obtain and the result of this method could be interfered by virus quantification and debris [62].

\section{Serological methods}

Unlike molecular methods, serological methods (also called antibody tests) can be applied to detect past and current SARS-CoV-2 infection and monitor the progress of the disease periods and immune response. They can detect the presence of antibodies (e.g. IgG, IgM, and IgA) in a COVID-19 patient's serum and plasma. Other biological fluids such as but not limited to saliva and sputum could be used as well. Antibodies are produced as a defense mechanism by the immune system against SARS-CoV-2. First, IgM is produced after a few days of infection and last for approximately two weeks which followed by $\lg G$ production that is last longer $[63,64]$. Thus, detecting $\lg M$ in a patient's sample indicates early-stage infection while detecting IgG indicates a current or prior infection [52]. In addition to lacking an early detection, accuracy is the main challenge of these approaches where crossover could occur with other antibodies that produced as a result of infection of other coronavirus family members such as SARS$\operatorname{CoV}[65,66]$.

\section{Lateral flow assay (LFA)}

It is one of the most popular serological method that has been applied in clinics to detect antigens [67], antibodies [68], and amplified nucleic acids [69, 70] in variant biological samples such as blood (serum or plasma) [71, 72] , urine [73], and saliva[74]. LFA is a paper-like membrane strip that is coated with two lines. The first line, the test line, contains anti-human $\lg \mathrm{G} / \operatorname{lgM}$ antibodies, while the second line, the control line, 
210 contains anti-rabbit IgG antibodies. After adding a patients specimen (e.g. blood) into

211 the sample well, $\lg \mathrm{G} / \mathrm{lgM}$ antibodies are moved by capillary action toward the lines

212 crossing through the conjugated pad where a specific conjugated antigen (e.g. gold

213 COVID-19 antigen conjugate) and rabbit-gold conjugated antibodies are impeded [75].

$214 \mathrm{IgG} / \mathrm{lg}$ M antibodies are interacted and made a complex with gold COVID-19 antigen

215 conjugate. The complex binds anti-human $\lg \mathrm{G} / \mathrm{lgM}$ antibodies and immobilizes at the

216 test line, while the rabbit-gold conjugate antibodies bind anti-rabbit IgG antibody and

217 immobilized at the control line. The result will be visible as a red line due to the

218 accumulation of gold particles. If both test and control lines appear red, the result is

219 positive and negative when only the control line appears red. If both lines disappear or

220 only the test line appears, the result is invalid (Fig. 3). The advantages of FLA are rapid

221 (10-30 minutes), cheap, no need for professional skills, and portable (POCT). It can be

222 done by 1-2 blood drops and the result is visualized by naked eyes without an

223 expensive equipment. The drawback of FLA is a qualitative method, tells the presence

224 or absence of antibodies against the virus without telling how much they were in a

225 patient's sample, and it less accurate compared to rRT-PCR. It was showed that FLA

226 has clinical $57 \%$ sensitivity and $100 \%$ specificity for $\lg M$ and $81 \%$ sensitivity and $100 \%$

227 specificity for lgG [76].

\section{Enzyme-linked immunosorbent assay (ELISA)}

229 It is another serological method and called enzyme immunoassay (EIA). ELISA is a 230 plate-based method that has been used for detecting and quantifying soluble

231 substances such as proteins and antibodies in clinic and research laboratories. It

232 includes direct and indirect formats [77]. The indirect ELISA, the most popular and more 
233

234

235

236

237

238

239

240

241

242

243

244

245

246

247

248

249

250

251

252

253

254

255

sensitive than the direct ELISA, an antigen (e.g. a recombinant protein ( $\mathrm{N}$ protein) of

SARS-CoV-2 virus) is coated onto the inner surface of 96-well or 384-well polystyrene plates [78]. A diluted patient's plasma which may have anti-SARS-CoV-2 IgG/lgM is added to the wells. The plate is incubated for one hour to allow the antibodies to interact with coated antigens. After washing the plate to eliminate unspecific interactions, a conjugated antibody with a reported enzyme such as horseradish peroxidase (HRP) or alkaline phosphatase $(A P)$ is added to form sandwich complexes $[79,80]$. These complexes are detected and quantified by adding a substrate (e.g. 3,3',5,5'tetramethylbenzidine) that is utilized by the report enzyme and leads to change in the reaction color [81, 82]. The color is detected and measured by a plate reader (Fig. 4). ELISA is relatively fast (2-5 hours) and cheap compared to rRT-PCR, and it is similar to FLA regard to accuracy. It has been reported that ELISA results were $50 \%(\lg G)$ and $81 \%(\lg M)$ for patients on day zero and became $81 \%(\lg G)$ and $100 \%(\lg M)$ on day five of SARS-CoV-2 infection [16]. Another study accomplished by Xiang et al. showed that using ELISA to detect IgM and IgG on day four of symptom onsite revealed a sensitivity of $77.3 \%$ and specificity of $100 \%$ for $\operatorname{lgM}$ while those were $83.3 \%$ and $95 \%$ respectively for $\lg G$ [64].

Worth mention that there are other serological methods that are less common than FLA and ELISA [83]. A colloidal gold immunochromatography assay (GICA), and Chemiluminescent immunoassay (CLIA) were developed to diagnose COVID-19; however, they have low sensitivity at the beginning of the infection [84, 85]. Pan et al. reported that the sensitivity of GICA were $11.1 \%$ on the first week and $92.9 \%$ on the second weeks after the onset of symptoms [86]. Neutralization assays, on the other 
256 hands, are standard methods for determining antibody efficacy (e.g. serum virus

257 neutralization (SVN) assay). They are used to check whether a patient has active

258 antibodies that can neutralize the SARS-CoV-2 infection $[87,88]$. These assays play a

259 key role in determining if an individual is eligible to donate his/her convalescent plasma

260 as a treatment for seriously ill people although such treatment has not been fully

261 validated [89].

Both molecular and serological methods are not perfect in terms of detecting COVID19 virus and each method has its own limitations [90]. Though molecular methods are more reliable than serological methods, both methods could give false results due to various reasons. For instance, incorrect sampling, inadequate viral material in the specimen, improper RNA extraction, cross-reactions with other viral species, contamination, and technical issues could lead to positive and negative false results. To overcome such issues and increase the certainty of given results, these methods can be followed by secondary diagnostic methods such as a chest CT scan and x-ray 270 imaging [91-93].

\section{Conclusion}

272 Scientists have made significant progress in the characterization of the COVID-19

273 virus and how to limit its spreading. Also, they are working hard on diagnostic methods and finding therapies and vaccines against the virus. Currently, neither an approved vaccine nor a specific antiviral treatment is available for COVID-19 disease. Thus, detecting SARS-CoV-2 at the early infectious stage by a rapid and accurate diagnostic method could save thousands of lives. In this review we have discussed and summarized the current knowledge about molecular and serological methods that have 
279

280

281

282

283

284

285

286

287

288

289

290

291

292

293

294

295

296

297

298

299

300

301

302

303

304

305

306

307

308

309

310

311

312

313

314

been used to detect SARS-CoV-2. Though the molecular methods are more expensive, slower, and less available than serological methods, they are more accurate and rRT-

PCR is the gold standard method among them (Table 4). Further research and

collaboration between scientists and companies are needed to overcome some

limitations of current methods and might find a new and better avenue to detect the

virus. For instance, standardized the methods, produce new and high-quality kits and

make them available at low cost will make the current methods more reliable.

\section{References}

1. Zhu, N., D. Zhang, W. Wang, X. Li, B. Yang, J. Song, X. Zhao, B. Huang, W. Shi, R. Lu, P. Niu, F. Zhan, X. Ma, D. Wang, W. Xu, G. Wu, G. F. Gao, W. Tan, Investigating China Novel Coronavirus, and Team Research, A Novel Coronavirus from Patients with Pneumonia in China, 2019. N Engl J Med, 2020. 382(8): p. 727-733.

2. Zhou, P., X. L. Yang, X. G. Wang, B. Hu, L. Zhang, W. Zhang, H. R. Si, Y. Zhu, B. Li, C. L. Huang, H. D. Chen, J. Chen, Y. Luo, H. Guo, R. D. Jiang, M. Q. Liu, Y. Chen, X. R. Shen, X. Wang, X. S. Zheng, K. Zhao, Q. J. Chen, F. Deng, L. L. Liu, B. Yan, F. X. Zhan, Y. Y. Wang, G. F. Xiao, and Z. L. Shi, A pneumonia outbreak associated with a new coronavirus of probable bat origin. Nature, 2020. 579(7798): p. 270-273.

3. Guo, Y. R., Q. D. Cao, Z. S. Hong, Y. Y. Tan, S. D. Chen, H. J. Jin, K. S. Tan, D. Y. Wang, and Y. Yan, The origin, transmission and clinical therapies on coronavirus disease 2019 (COVID-19) outbreak - an update on the status. Mil Med Res, 2020. 7(1): p. 11.

4. Wu, F., S. Zhao, B. Yu, Y. M. Chen, W. Wang, Z. G. Song, Y. Hu, Z. W. Tao, J. H. Tian, Y. Y. Pei, M. L. Yuan, Y. L. Zhang, F. H. Dai, Y. Liu, Q. M. Wang, J. J. Zheng, L. Xu, E. C. Holmes, and Y. Z. Zhang, A new coronavirus associated with human respiratory disease in China. Nature, 2020. 579(7798): p. 265-269.

5. Lu, R., X. Zhao, J. Li, P. Niu, B. Yang, H. Wu, W. Wang, H. Song, B. Huang, N. Zhu, Y. Bi, X. Ma, F. Zhan, L. Wang, T. Hu, H. Zhou, Z. Hu, W. Zhou, L. Zhao, J. Chen, Y. Meng, J. Wang, Y. Lin, J. Yuan, Z. Xie, J. Ma, W. J. Liu, D. Wang, W. Xu, E. C. Holmes, G. F. Gao, G. Wu, W. Chen, W. Shi, and W. Tan, Genomic characterisation and epidemiology of 2019 novel coronavirus: implications for virus origins and receptor binding. Lancet, 2020. 395(10224): p. 565-574.

6. Song, Z., Y. Xu, L. Bao, L. Zhang, P. Yu, Y. Qu, H. Zhu, W. Zhao, Y. Han, and C. Qin, From SARS to MERS, Thrusting Coronaviruses into the Spotlight. Viruses, 2019. 11(1).

7. de Wilde, A. H., E. J. Snijder, M. Kikkert, and M. J. van Hemert, Host Factors in Coronavirus Replication. Curr Top Microbiol Immunol, 2018. 419: p. 1-42.

8. Cui, J., F. Li, and Z. L. Shi, Origin and evolution of pathogenic coronaviruses. Nat Rev Microbiol, 2019. 17(3): p. 181-192. 
$3159 . \quad$ Chen, Y., Q. Liu, and D. Guo, Emerging coronaviruses: Genome structure, replication, and pathogenesis. J Med Virol, 2020. 92(4): p. 418-423.

10. Yang, J. and Y. Zhang, Protein Structure and Function Prediction Using I-TASSER. Curr Protoc Bioinformatics, 2015. 52: p. 58 1-5 815.

11. Genome-wide structure and function modeling of SARS-CoV-2. 2020; Available from: https://zhanglab.ccmb.med.umich.edu/COVID-19/.

12. Jiang, S., C. Hillyer, and L. Du, Neutralizing Antibodies against SARS-CoV-2 and Other Human Coronaviruses. Trends Immunol, 2020. 41(5): p. 355-359.

13. Du, L., Y. He, Y. Zhou, S. Liu, B. J. Zheng, and S. Jiang, The spike protein of SARS-CoV--a target for vaccine and therapeutic development. Nat Rev Microbiol, 2009. 7(3): p. 226-36.

14. Cascella, M., M. Rajnik, A. Cuomo, S. C. Dulebohn, and R. Di Napoli, Features, Evaluation and Treatment Coronavirus (COVID-19), in StatPearls. 2020: Treasure Island (FL).

15. Yang, P. and X. Wang, COVID-19: a new challenge for human beings. Cell Mol Immunol, 2020. 17(5): p. 555-557.

16. Zhang, W., R. H. Du, B. Li, X. S. Zheng, X. L. Yang, B. Hu, Y. Y. Wang, G. F. Xiao, B. Yan, Z. L. Shi, and $\mathrm{P}$. Zhou, Molecular and serological investigation of 2019-nCoV infected patients: implication of multiple shedding routes. Emerg Microbes Infect, 2020. 9(1): p. 386-389.

17. Liu, J., X. Zheng, Q. Tong, W. Li, B. Wang, K. Sutter, M. Trilling, M. Lu, U. Dittmer, and D. Yang, Overlapping and discrete aspects of the pathology and pathogenesis of the emerging human pathogenic coronaviruses SARS-CoV, MERS-CoV, and 2019-nCoV. J Med Virol, 2020. 92(5): p. 491-494.

18. Pujadas, E., F. Chaudhry, R. McBride, F. Richter, S. Zhao, A. Wajnberg, G. Nadkarni, B. S. Glicksberg, J. Houldsworth, and C. Cordon-Cardo, SARS-CoV-2 viral load predicts COVID-19 mortality. Lancet Respir Med, 2020.

19. Kreutz, R., E. A. E. Algharably, M. Azizi, P. Dobrowolski, T. Guzik, A. Januszewicz, A. Persu, A. Prejbisz, T. G. Riemer, J. G. Wang, and M. Burnier, Hypertension, the renin-angiotensin system, and the risk of lower respiratory tract infections and lung injury: implications for COVID-19. Cardiovasc Res, 2020.

20. Schiffrin, E. L., J. M. Flack, S. Ito, P. Muntner, and R. C. Webb, Hypertension and COVID-19. Am J Hypertens, 2020. 33(5): p. 373-374.

21. Hussain, A., B. Bhowmik, and N. C. do Vale Moreira, COVID-19 and diabetes: Knowledge in progress. Diabetes Res Clin Pract, 2020. 162: p. 108142.

22. Fang, L., G. Karakiulakis, and M. Roth, Are patients with hypertension and diabetes mellitus at increased risk for COVID-19 infection? Lancet Respir Med, 2020. 8(4): p. e21.

23. Lippi, G. and B. M. Henry, Chronic obstructive pulmonary disease is associated with severe coronavirus disease 2019 (COVID-19). Respir Med, 2020. 167: p. 105941.

24. Muniyappa, R. and S. Gubbi, COVID-19 pandemic, coronaviruses, and diabetes mellitus. Am J Physiol Endocrinol Metab, 2020. 318(5): p. E736-E741.

25. Emami, A., F. Javanmardi, N. Pirbonyeh, and A. Akbari, Prevalence of Underlying Diseases in Hospitalized Patients with COVID-19: a Systematic Review and Meta-Analysis. Arch Acad Emerg Med, 2020. 8(1): p. e35.

26. Wang, D., B. Hu, C. Hu, F. Zhu, X. Liu, J. Zhang, B. Wang, H. Xiang, Z. Cheng, Y. Xiong, Y. Zhao, Y. Li, X. Wang, and Z. Peng, Clinical Characteristics of 138 Hospitalized Patients With 2019 Novel Coronavirus-Infected Pneumonia in Wuhan, China. JAMA, 2020.

27. Guan, W. J., Z. Y. Ni, Y. Hu, W. H. Liang, C. Q. Ou, J. X. He, L. Liu, H. Shan, C. L. Lei, D. S. C. Hui, B. Du, L. J. Li, G. Zeng, K. Y. Yuen, R. C. Chen, C. L. Tang, T. Wang, P. Y. Chen, J. Xiang, S. Y. Li, J. L. Wang, Z. J. Liang, Y. X. Peng, L. Wei, Y. Liu, Y. H. Hu, P. Peng, J. M. Wang, J. Y. Liu, Z. Chen, G. Li, Z. J. Zheng, S. Q. Qiu, J. Luo, C. J. Ye, S. Y. Zhu, N. S. Zhong, and Covid China Medical Treatment 
Expert Group for, Clinical Characteristics of Coronavirus Disease 2019 in China. N Engl J Med, 2020. 382(18): p. 1708-1720.

28. Li, Q., X. Guan, P. Wu, X. Wang, L. Zhou, Y. Tong, R. Ren, K. S. M. Leung, E. H. Y. Lau, J. Y. Wong, X. Xing, N. Xiang, Y. Wu, C. Li, Q. Chen, D. Li, T. Liu, J. Zhao, M. Liu, W. Tu, C. Chen, L. Jin, R. Yang, Q. Wang, S. Zhou, R. Wang, H. Liu, Y. Luo, Y. Liu, G. Shao, H. Li, Z. Tao, Y. Yang, Z. Deng, B. Liu, Z. Ma, Y. Zhang, G. Shi, T. T. Y. Lam, J. T. Wu, G. F. Gao, B. J. Cowling, B. Yang, G. M. Leung, and Z. Feng, Early Transmission Dynamics in Wuhan, China, of Novel Coronavirus-Infected Pneumonia. N Engl J Med, 2020. 382(13): p. 1199-1207.

29. Tian, S., N. Hu, J. Lou, K. Chen, X. Kang, Z. Xiang, H. Chen, D. Wang, N. Liu, D. Liu, G. Chen, Y. Zhang, D. Li, J. Li, H. Lian, S. Niu, L. Zhang, and J. Zhang, Characteristics of COVID-19 infection in Beijing. J Infect, 2020. 80(4): p. 401-406.

30. Chan, J. F., S. Yuan, K. H. Kok, K. K. To, H. Chu, J. Yang, F. Xing, J. Liu, C. C. Yip, R. W. Poon, H. W. Tsoi, S. K. Lo, K. H. Chan, V. K. Poon, W. M. Chan, J. D. Ip, J. P. Cai, V. C. Cheng, H. Chen, C. K. Hui, and K. Y. Yuen, A familial cluster of pneumonia associated with the 2019 novel coronavirus indicating person-to-person transmission: a study of a family cluster. Lancet, 2020. 395(10223): p. 514-523.

31. Davies, N. G., P. Klepac, Y. Liu, K. Prem, M. Jit, Cmmid Covid- working group, and R. M. Eggo, Age-dependent effects in the transmission and control of COVID-19 epidemics. Nat Med, 2020.

32. Lauer, S. A., K. H. Grantz, Q. Bi, F. K. Jones, Q. Zheng, H. R. Meredith, A. S. Azman, N. G. Reich, and J. Lessler, The Incubation Period of Coronavirus Disease 2019 (COVID-19) From Publicly Reported Confirmed Cases: Estimation and Application. Ann Intern Med, 2020. 172(9): p. 577582.

33. Huang, C., Y. Wang, X. Li, L. Ren, J. Zhao, Y. Hu, L. Zhang, G. Fan, J. Xu, X. Gu, Z. Cheng, T. Yu, J. Xia, Y. Wei, W. Wu, X. Xie, W. Yin, H. Li, M. Liu, Y. Xiao, H. Gao, L. Guo, J. Xie, G. Wang, R. Jiang, Z. Gao, Q. Jin, J. Wang, and B. Cao, Clinical features of patients infected with 2019 novel coronavirus in Wuhan, China. Lancet, 2020. 395(10223): p. 497-506.

34. Sohrabi, C., Z. Alsafi, N. O'Neill, M. Khan, A. Kerwan, A. Al-Jabir, C. losifidis, and R. Agha, World Health Organization declares global emergency: A review of the 2019 novel coronavirus (COVID19). Int J Surg, 2020. 76: p. 71-76.

35. Wei, Y., Y. Lu, L. Xia, X. Yuan, G. Li, X. Li, L. Liu, W. Liu, P. Zhou, C. Y. Wang, and H. Zhang, Analysis of 2019 novel coronavirus infection and clinical characteristics of outpatients: An epidemiological study from a fever clinic in Wuhan, China. J Med Virol, 2020.

36. Kooraki, S., M. Hosseiny, L. Myers, and A. Gholamrezanezhad, Coronavirus (COVID-19) Outbreak: What the Department of Radiology Should Know. J Am Coll Radiol, 2020. 17(4): p. 447-451.

37. COVID-19 symptoms. 2020; Available from: https://www.who.int/healthtopics/coronavirus\#tab=tab_3.

38. Drew, D. A., L. H. Nguyen, C. J. Steves, C. Menni, M. Freydin, T. Varsavsky, C. H. Sudre, M. J. Cardoso, S. Ourselin, J. Wolf, T. D. Spector, A. T. Chan, and Cope Consortium, Rapid implementation of mobile technology for real-time epidemiology of COVID-19. Science, 2020. 368(6497): p. 1362-1367.

39. Menni, C., A. M. Valdes, M. B. Freidin, C. H. Sudre, L. H. Nguyen, D. A. Drew, S. Ganesh, T. Varsavsky, M. J. Cardoso, J. S. El-Sayed Moustafa, A. Visconti, P. Hysi, R. C. E. Bowyer, M. Mangino, M. Falchi, J. Wolf, S. Ourselin, A. T. Chan, C. J. Steves, and T. D. Spector, Real-time tracking of self-reported symptoms to predict potential COVID-19. Nat Med, 2020.

40. de Wit, E., N. van Doremalen, D. Falzarano, and V. J. Munster, SARS and MERS: recent insights into emerging coronaviruses. Nat Rev Microbiol, 2016. 14(8): p. 523-34.

41. Coronavirus resource center. 2020; Available from: https://coronavirus.jhu.edu/us-map. 
410 42. Resources for Laboratories Working on Coronavirus (COVID-19). 2020; Available from:

411 https://www.cdc.gov.

413

414

415

416

43. Corman, V. M., O. Landt, M. Kaiser, R. Molenkamp, A. Meijer, D. K. Chu, T. Bleicker, S. Brunink, J. Schneider, M. L. Schmidt, D. G. Mulders, B. L. Haagmans, B. van der Veer, S. van den Brink, L. Wijsman, G. Goderski, J. L. Romette, J. Ellis, M. Zambon, M. Peiris, H. Goossens, C. Reusken, M. P. Koopmans, and C. Drosten, Detection of 2019 novel coronavirus (2019-nCoV) by real-time RTPCR. Euro Surveill, 2020. 25(3).

44. Amrane, S., H. Tissot-Dupont, B. Doudier, C. Eldin, M. Hocquart, M. Mailhe, P. Dudouet, E. Ormieres, L. Ailhaud, P. Parola, J. C. Lagier, P. Brouqui, C. Zandotti, L. Ninove, L. Luciani, C. Boschi, B. La Scola, D. Raoult, M. Million, P. Colson, and P. Gautret, Rapid viral diagnosis and ambulatory management of suspected COVID-19 cases presenting at the infectious diseases referral hospital in Marseille, France, - January 31st to March 1st, 2020: A respiratory virus snapshot. Travel Med Infect Dis, 2020: p. 101632.

45. Capobianchi, M. R., M. Rueca, F. Messina, E. Giombini, F. Carletti, F. Colavita, C. Castilletti, E. Lalle, L. Bordi, F. Vairo, E. Nicastri, G. Ippolito, C. E. M. Gruber, and B. Bartolini, Molecular characterization of SARS-CoV-2 from the first case of COVID-19 in Italy. Clin Microbiol Infect, 2020. 26(7): p. 954-956.

46. Chu, D. K. W., Y. Pan, S. M. S. Cheng, K. P. Y. Hui, P. Krishnan, Y. Liu, D. Y. M. Ng, C. K. C. Wan, P. Yang, Q. Wang, M. Peiris, and L. L. M. Poon, Molecular Diagnosis of a Novel Coronavirus (2019nCoV) Causing an Outbreak of Pneumonia. Clin Chem, 2020. 66(4): p. 549-555.

47. Peihua Niu, Roujian Lu, Li Zhao, Huijuan Wang, Baoying Huang, Fei Ye, Wenling Wang, and Wenjie Tan, Three Novel Real-Time RT-PCR Assays for Detection of COVID-19 Virus. China CDC Weekly, 2020. 2(25): 453-457.

48. Naganori Nao, 1Kazuya Shirato, 2Harutaka Katano, 1Shutoku Matsuyama, and 1Makoto Takeda Detection of second case of 2019-nCoV infection in Japan. 2020.

49. Xia, J., J. Tong, M. Liu, Y. Shen, and D. Guo, Evaluation of coronavirus in tears and conjunctival secretions of patients with SARS-CoV-2 infection. J Med Virol, 2020. 92(6): p. 589-594.

50. Carter, L. J., L. V. Garner, J. W. Smoot, Y. Li, Q. Zhou, C. J. Saveson, J. M. Sasso, A. C. Gregg, D. J. Soares, T. R. Beskid, S. R. Jervey, and C. Liu, Assay Techniques and Test Development for COVID19 Diagnosis. ACS Cent Sci, 2020. 6(5): p. 591-605.

51. Team, Covid- Investigation, Clinical and virologic characteristics of the first 12 patients with coronavirus disease 2019 (COVID-19) in the United States. Nat Med, 2020. 26(6): p. 861-868.

52. Sethuraman, N., S. S. Jeremiah, and A. Ryo, Interpreting Diagnostic Tests for SARS-CoV-2. JAMA, 2020.

53. Kubina, R. and A. Dziedzic, Molecular and Serological Tests for COVID-19 a Comparative Review of SARS-CoV-2 Coronavirus Laboratory and Point-of-Care Diagnostics. Diagnostics (Basel), 2020. 10(6).

54. Notomi, T., H. Okayama, H. Masubuchi, T. Yonekawa, K. Watanabe, N. Amino, and T. Hase, Loopmediated isothermal amplification of DNA. Nucleic Acids Res, 2000. 28(12): p. E63.

55. ID NOW ${ }^{T M}$ COVID-19. 2020; Available from: https://www.alere.com/en/home/productdetails/id-now-covid-19.html.

56. Harrington, A., B. Cox, J. Snowdon, J. Bakst, E. Ley, P. Grajales, J. Maggiore, and S. Kahn, Comparison of Abbott ID Now and Abbott m2000 methods for the detection of SARS-CoV-2 from nasopharyngeal and nasal swabs from symptomatic patients. J Clin Microbiol, 2020.

57. Wang, D., J. Yu, Y. Wang, M. Zhang, P. Li, M. Liu, and Y. Liu, Development of a real-time loopmediated isothermal amplification (LAMP) assay and visual LAMP assay for detection of African swine fever virus (ASFV). J Virol Methods, 2020. 276: p. 113775. 
457

458

459

460

461

462

463

464

465

466

467

468

469

470

471

472

473

474

475

476

477

478

479

480

481

482

483

484

485

486

487

488

489

490

491

492

493

494

495

496

497

498

499

500

501

502

503
58. Lamb, L. E., S. N. Bartolone, E. Ward, and M. B. Chancellor, Rapid detection of novel coronavirus/Severe Acute Respiratory Syndrome Coronavirus 2 (SARS-CoV-2) by reverse transcription-loop-mediated isothermal amplification. PLoS One, 2020. 15(6): p. e0234682.

59. Hong, T. C., Q. L. Mai, D. V. Cuong, M. Parida, H. Minekawa, T. Notomi, F. Hasebe, and K. Morita, Development and evaluation of a novel loop-mediated isothermal amplification method for rapid detection of severe acute respiratory syndrome coronavirus. J Clin Microbiol, 2004. 42(5): p. 1956-61.

60. Broughton, J. P., X. Deng, G. Yu, C. L. Fasching, J. Singh, J. Streithorst, A. Granados, A. SotomayorGonzalez, K. Zorn, A. Gopez, E. Hsu, W. Gu, S. Miller, C. Y. Pan, H. Guevara, D. A. Wadford, J. S. Chen, and C. Y. Chiu, Rapid Detection of 2019 Novel Coronavirus SARS-CoV-2 Using a CRISPRbased DETECTR Lateral Flow Assay. medRxiv, 2020.

61. Amer, H. M., A. Abd El Wahed, M. A. Shalaby, F. N. Almajhdi, F. T. Hufert, and M. Weidmann, $A$ new approach for diagnosis of bovine coronavirus using a reverse transcription recombinase polymerase amplification assay. J Virol Methods, 2013. 193(2): p. 337-40.

62. Yu, L., S. Wu, X. Hao, X. Dong, L. Mao, V. Pelechano, W. H. Chen, and X. Yin, Rapid detection of COVID-19 coronavirus using a reverse transcriptional loop-mediated isothermal amplification (RT-LAMP) diagnostic platform. Clin Chem, 2020.

63. To, K. K., O. T. Tsang, W. S. Leung, A. R. Tam, T. C. Wu, D. C. Lung, C. C. Yip, J. P. Cai, J. M. Chan, T. S. Chik, D. P. Lau, C. Y. Choi, L. L. Chen, W. M. Chan, K. H. Chan, J. D. Ip, A. C. Ng, R. W. Poon, C. T. Luo, V. C. Cheng, J. F. Chan, I. F. Hung, Z. Chen, H. Chen, and K. Y. Yuen, Temporal profiles of viral load in posterior oropharyngeal saliva samples and serum antibody responses during infection by SARS-CoV-2: an observational cohort study. Lancet Infect Dis, 2020. 20(5): p. 565-574.

64. Xiang, F., X. Wang, X. He, Z. Peng, B. Yang, J. Zhang, Q. Zhou, H. Ye, Y. Ma, H. Li, X. Wei, P. Cai, and W. L. Ma, Antibody Detection and Dynamic Characteristics in Patients with COVID-19. Clin Infect Dis, 2020.

65. Important Information on the Use of Serological (Antibody) Tests for COVID-19-Letter to Health Care Providers. June 19, 2020; Available from: https://www.fda.gov/.

66. Maxim, L. D., R. Niebo, and M. J. Utell, Screening tests: a review with examples. Inhal Toxicol, 2014. 26(13): p. 811-28.

67. Boisen, M. L., D. Oottamasathien, A. B. Jones, M. M. Millett, D. S. Nelson, Z. A. Bornholdt, M. L. Fusco, D. M. Abelson, S. Oda, J. N. Hartnett, M. M. Rowland, M. L. Heinrich, M. Akdag, A. Goba, M. Momoh, M. Fullah, F. Baimba, M. Gbakie, S. Safa, R. Fonnie, L. Kanneh, R. W. Cross, J. B. Geisbert, T. W. Geisbert, P. C. Kulakosky, D. S. Grant, J. G. Shaffer, J. S. Schieffelin, R. B. Wilson, E. O. Saphire, L. M. Branco, R. F. Garry, S. H. Khan, K. R. Pitts, and Consortium Viral Hemorrhagic Fever, Development of Prototype Filovirus Recombinant Antigen Immunoassays. J Infect Dis, 2015. 212 Suppl 2: p. S359-67.

68. Nielsen, K., W. L. Yu, L. Kelly, R. Bermudez, T. Renteria, A. Dajer, E. Gutierrez, J. Williams, J. Algire, and S. T. de Eschaide, Development of a lateral flow assay for rapid detection of bovine antibody to Anaplasma marginale. J Immunoassay Immunochem, 2008. 29(1): p. 10-8.

69. Koczula, K. M. and A. Gallotta, Lateral flow assays. Essays Biochem, 2016. 60(1): p. 111-20.

70. Rohrman, B. A., V. Leautaud, E. Molyneux, and R. R. Richards-Kortum, A lateral flow assay for quantitative detection of amplified HIV-1 RNA. PLoS One, 2012. 7(9): p. e45611.

71. Schramm, E. C., N. R. Staten, Z. Zhang, S. S. Bruce, C. Kellner, J. P. Atkinson, V. C. Kyttaris, G. C. Tsokos, M. Petri, E. Sander Connolly, and P. K. Olson, A quantitative lateral flow assay to detect complement activation in blood. Anal Biochem, 2015. 477: p. 78-85.

72. Magambo, K. A., S. E. Kalluvya, S. W. Kapoor, J. Seni, A. A. Chofle, D. W. Fitzgerald, and J. A. Downs, Utility of urine and serum lateral flow assays to determine the prevalence and predictors 
504

505

506

507

508

509

510

511

512

513

514

515

516

517

518

519

520

521

522

523

524

525

526

527

528

529

530

531

532

533

534

535

536

537

538

539

540

541

542

543

544

545

546

547

548

549

of cryptococcal antigenemia in HIV-positive outpatients beginning antiretroviral therapy in Mwanza, Tanzania. J Int AIDS Soc, 2014. 17: p. 19040.

73. Moreno, M. L., A. Cebolla, A. Munoz-Suano, C. Carrillo-Carrion, I. Comino, A. Pizarro, F. Leon, A. Rodriguez-Herrera, and C. Sousa, Detection of gluten immunogenic peptides in the urine of patients with coeliac disease reveals transgressions in the gluten-free diet and incomplete mucosal healing. Gut, 2017. 66(2): p. 250-257.

74. Carrio, A., C. Sampedro, J. L. Sanchez-Lopez, M. Pimienta, and P. Campoy, Automated Low-Cost Smartphone-Based Lateral Flow Saliva Test Reader for Drugs-of-Abuse Detection. Sensors (Basel), 2015. 15(11): p. 29569-93.

75. Parolo, C., A. de la Escosura-Muniz, and A. Merkoci, Enhanced lateral flow immunoassay using gold nanoparticles loaded with enzymes. Biosens Bioelectron, 2013. 40(1): p. 412-6.

76. Jie Xiang, Mingzhe Yan, Hongze Li, Ting Liu, Chenyao Lin, Shuang Huang, Changxin Shen, Evaluation of Enzyme-Linked Immunoassay and Colloidal Gold-Immunochromatographic Assay Kit for Detection of Novel Coronavirus (SARS-Cov-2) Causing an Outbreak of Pneumonia (COVID19). medRxiv, 2020.

77. Zhang, Y., W. A. Brooks, D. Goswami, M. Rahman, S. P. Luby, and D. D. Erdman, A duplex recombinant viral nucleoprotein microbead immunoassay for simultaneous detection of seroresponses to human respiratory syncytial virus and metapneumovirus infections. J Virol Methods, 2014. 206: p. 55-62.

78. Gao, X., H. Zhou, C. Wu, Y. Xiao, L. Ren, G. Paranhos-Baccala, L. Guo, and J. Wang, Antibody against nucleocapsid protein predicts susceptibility to human coronavirus infection. J Infect, 2015. 71(5): p. 599-602.

79. Dongyang Li, Yibin Ying, Jian Wu, Reinhard Niessner \& Dietmar Knopp, Comparison of monomeric and polymeric horseradish peroxidase as labels in competitive ELISA for small molecule detection. Microchim Acta 2013.

80. Zhang, Z., Z. Chen, S. Wang, F. Cheng, and L. Chen, lodine-Mediated Etching of Gold Nanorods for Plasmonic ELISA Based on Colorimetric Detection of Alkaline Phosphatase. ACS Appl Mater Interfaces, 2015. 7(50): p. 27639-45.

81. Madersbacher, S. and P. Berger, Double wavelength measurement of 3,3',5,5'tetramethylbenzidine (TMB) provides a three-fold enhancement of the ELISA measuring range. J Immunol Methods, 1991. 138(1): p. 121-4.

82. Lee, M., B. A. Harrison, and G. E. Lewis, Jr., A rapid sporozoite ELISA using 3, 3',5,5'tetramethylbenzidine as the substrate chromogen. Am J Trop Med Hyg, 1990. 42(4): p. 314-9.

83. La Marca, A., M. Capuzzo, T. Paglia, L. Roli, T. Trenti, and S. M. Nelson, Testing for SARS-CoV-2 (COVID-19): a systematic review and clinical guide to molecular and serological in-vitro diagnostic assays. Reprod Biomed Online, 2020. 41(3): p. 483-499.

84. Infantino, M., V. Grossi, B. Lari, R. Bambi, A. Perri, M. Manneschi, G. Terenzi, I. Liotti, G. Ciotta, C. Taddei, M. Benucci, P. Casprini, F. Veneziani, S. Fabbri, A. Pompetti, and M. Manfredi, Diagnostic accuracy of an automated chemiluminescent immunoassay for anti-SARS-CoV-2 IgM and IgG antibodies: an Italian experience. J Med Virol, 2020.

85. Zhang P, Gao Q, Wang T, Ke Y, Mo F, Jia R, Liu W, Liu L, Zheng S, Liu Y, Li L, Wang Y, Xu L, Hao K, Yang R, Li S, Lin C, Zhao Y, Evaluation of recombinant nucleocapsid and spike proteins for serological diagnosis of novel coronavirus disease 2019 (COVID-19). medRxiv, 2020.

86. Pan, Y., X. Li, G. Yang, J. Fan, Y. Tang, J. Zhao, X. Long, S. Guo, Z. Zhao, Y. Liu, H. Hu, H. Xue, and Y. $\mathrm{Li}$, Serological immunochromatographic approach in diagnosis with SARS-CoV-2 infected COVID19 patients. J Infect, 2020. 81(1): p. e28-e32. 
550

551

552

553

554

555

556

557

558

559

560

561

562

563

564

565

566

567

568

569

570

571

572

573

574

575

576

577

578

579

580

581

582

583

584

585

586

87. Gauger, P. C. and A. L. Vincent, Serum Virus Neutralization Assay for Detection and Quantitation of Serum Neutralizing Antibodies to Influenza A Virus in Swine. Methods Mol Biol, 2020. 2123: p. 321-333.

88. Muruato, A. E., C. R. Fontes-Garfias, P. Ren, M. A. Garcia-Blanco, V. D. Menachery, X. Xie, and P. $\mathrm{Y}$. Shi, A high-throughput neutralizing antibody assay for COVID-19 diagnosis and vaccine evaluation. bioRxiv, 2020.

89. Shen, C., Z. Wang, F. Zhao, Y. Yang, J. Li, J. Yuan, F. Wang, D. Li, M. Yang, L. Xing, J. Wei, H. Xiao, Y. Yang, J. Qu, L. Qing, L. Chen, Z. Xu, L. Peng, Y. Li, H. Zheng, F. Chen, K. Huang, Y. Jiang, D. Liu, Z. Zhang, Y. Liu, and L. Liu, Treatment of 5 Critically III Patients With COVID-19 With Convalescent Plasma. JAMA, 2020.

90. Bisoffi, Z., E. Pomari, M. Deiana, C. Piubelli, N. Ronzoni, A. Beltrame, G. Bertoli, N. Riccardi, F. Perandin, F. Formenti, F. Gobbi, D. Buonfrate, and R. Silva, Sensitivity, Specificity and Predictive Values of Molecular and Serological Tests for COVID-19: A Longitudinal Study in Emergency Room. Diagnostics (Basel), 2020. 10(9).

91. Yang, W., A. Sirajuddin, X. Zhang, G. Liu, Z. Teng, S. Zhao, and M. Lu, The role of imaging in 2019 novel coronavirus pneumonia (COVID-19). Eur Radiol, 2020.

92. Wang, C., P. W. Horby, F. G. Hayden, and G. F. Gao, A novel coronavirus outbreak of global health concern. Lancet, 2020. 395(10223): p. 470-473.

93. Wong, H. Y. F., H. Y. S. Lam, A. H. Fong, S. T. Leung, T. W. Chin, C. S. Y. Lo, M. M. Lui, J. C. Y. Lee, K. W. Chiu, T. Chung, E. Y. P. Lee, E. Y. F. Wan, F. N. I. Hung, T. P. W. Lam, M. Kuo, and M. Y. Ng, Frequency and Distribution of Chest Radiographic Findings in COVID-19 Positive Patients. Radiology, 2019: p. 201160.

\section{List of Figures}

\section{Figure1: Workflow summary of molecular and serological detection methods of}

\section{COVID-19. The figure is created with BioRender.com.}

\section{Figure 2: Schematic flowchart of molecular detection methods for COVID-19} virus.

(A) A viral RNA is directly amplified and detected from the sample by isothermal amplification method (e.g. ID NOW COVID-19). (B) The standard rRT-PCR method is illustrated where a viral RNA is extracted and converted into cDNA. Specific areas of cDNA (target genes) are amplified and detected by rRT-PCR. (C) demonstration of CRISPR-Cas 12 based method. After amplifying specific areas of extracted viral RNA, the Cas 12 enzyme recognizes specific sequences and then cleaves the ssDNA probe. The cleavage probes are visualized as a red line in the lateral flow strip. The figure is created with BioRender.com. 
587 Figure 3: Schematic flowchart of FLA.

588 A sample is loaded in the sample well $(A)$ and incubated to allow the capillary action to move sample antibodies ( $\mathrm{lgG} / \mathrm{lgM}$ ) forward (B). Gold COVID-19 antigen conjugates from the conjugate pad recognize and interact with sample antibodies forming complexes (C) that are immobilized by anti-human lgG/lgM antibodies and display the test red line (D). Control antibodies (rabbit- gold conjugates) are immobilized by antirabbit IgG antibodies and show the control red line (E). (F) FLA results possibilities are illustrated. The figure is created with BioRender.com.

595

596

597

598

599

600

601

602

603

604

605

606

607

608

609

610

611

612

613

614

615

616

617

618

619

Figure 4: Schematic flowchart of indirect ELISA.

A coated SARS-CoV-2 protein (antigen) onto wells of ELISA plate (A) interacts with the first antibody (anti-SARS-CoV-2 antibody) that is in a patient's sample (B). (C) After adding a secondary antibody (a conjugated antibody), it recognizes and interacts with the first antibodies. The reaction is developed by adding a substrate (D) which is cleaved by the conjugated enzyme and changes the reaction color after incubation (E) and $(F)$, respectively. $(G)$ Results are read by ELISA plate reader. The figure is created with BioRender.com.

\section{List of Tables}

Table 1:

Primers and probes that have been recommended by the U.S.CDC to detect SARS-CoV-2 by rRT-PCR.

\section{Table 2:}

Expected results and their interpretations of rRT-PCR method for COVID-19 specimens.

\section{Table 3:}

Expected results and their interpretations of SARS-CoV-2 DETECTR method for COVID-19 specimens.

\section{Table 4:}

Comparison between molecular and serological methods for detecting COVID-19 virus.

\section{Supplementary Tables}

Table S1: 
620 Primers and probes that have been recommended by other institutions to perform 621 rRT-PCR and detect SARS-CoV-2.

622 Table S2:

623 The rRT-PCR controls with expected results and interpretations.

624

625 
Figure 1

Workflow summary of molecular and serological detection methods of COVID-19. The figure is created with BioRender.com.

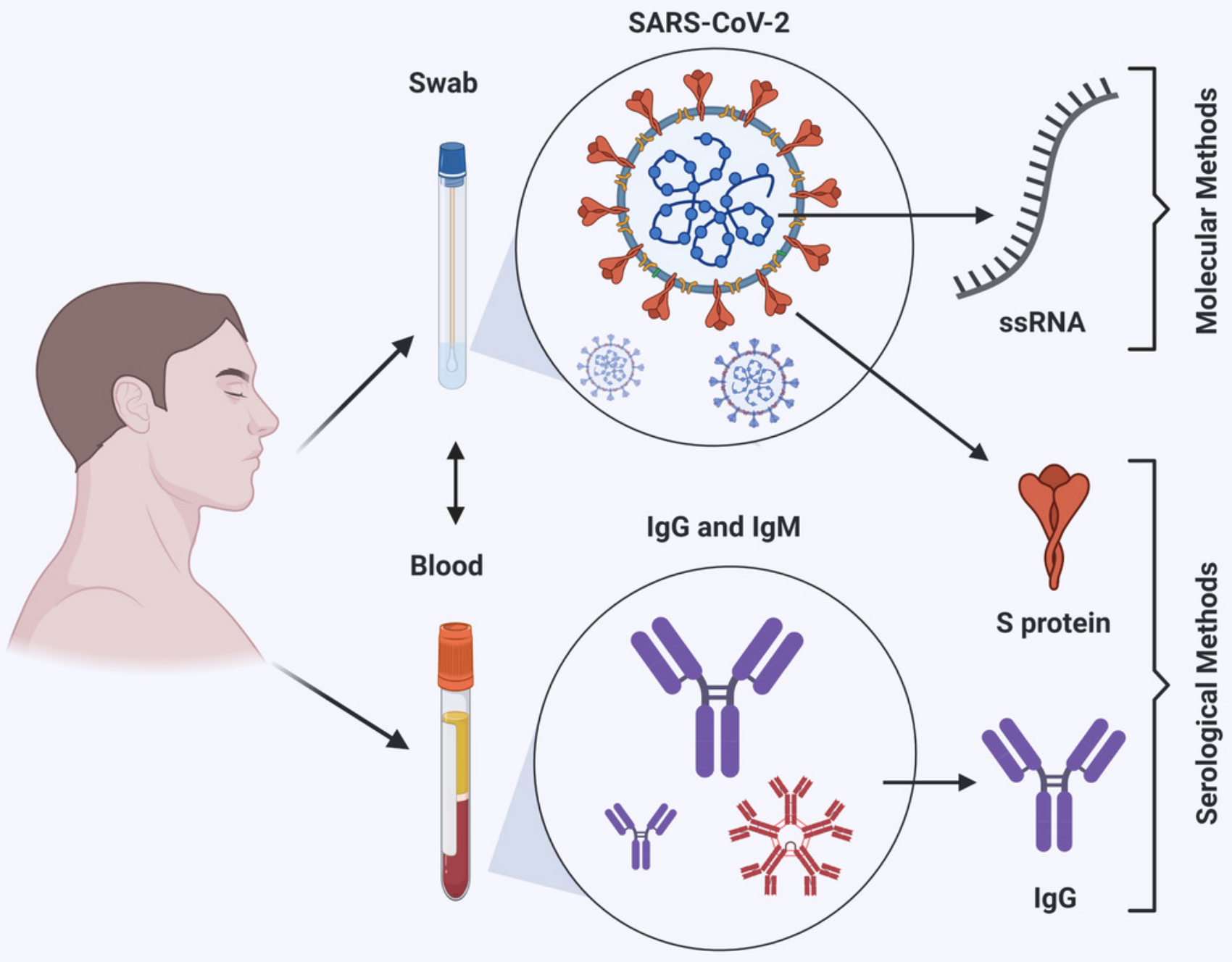




\section{Figure 2}

Schematic flowchart of molecular detection methods for COVID-19 virus.

(A) A viral RNA is directly amplified and detected from the sample by isothermal amplification method (e.g. ID NOW COVID-19). (B) The standard rRT-PCR method is illustrated where a viral RNA is extracted and converted into CDNA. Specific areas of CDNA (target genes) are amplified and detected by rRT-PCR. (C) demonstration of CRISPR-Cas12 based method. After amplifying specific areas of extracted viral RNA, the Cas12 enzyme recognizes specific sequences and then cleaves the ssDNA probe. The cleavage probes are visualized as a red line in the lateral flow strip. The figure is created with BioRender.com. 


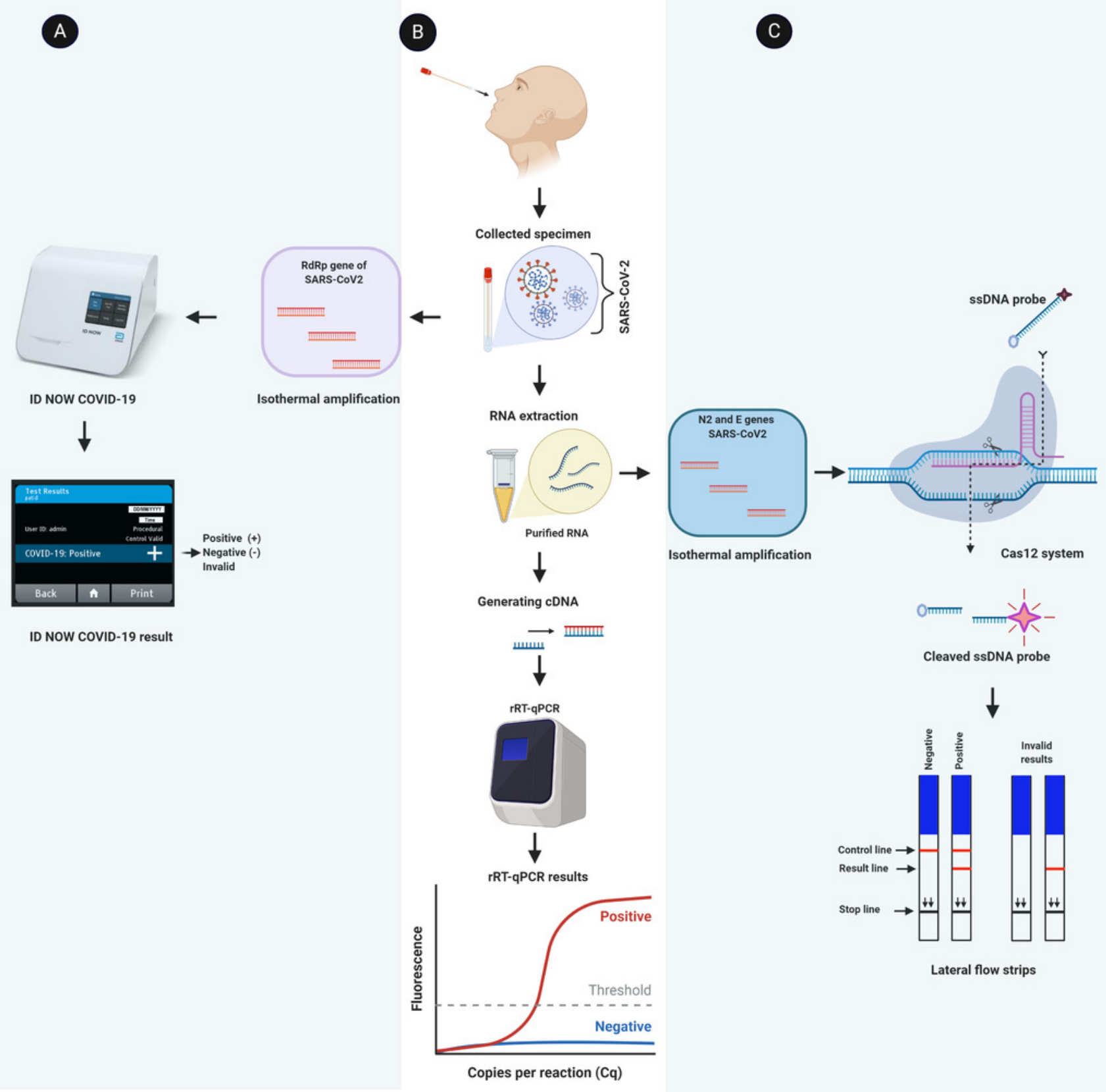




\section{Figure 3}

Schematic flowchart of FLA.

A sample is loaded in the sample well (A) and incubated to allow the capillary action to move sample antibodies (IgG/lgM) forward (B). Gold COVID-19 antigen conjugates from the conjugate pad recognize and interact with sample antibodies forming complexes (C) that are immobilized by anti-human IgG/lgM antibodies and display the test red line (D). Control antibodies (rabbit- gold conjugates) are immobilized by anti-rabbit IgG antibodies and show the control red line (E). (F) FLA results possibilities are illustrated. The figure is created with BioRender.com.
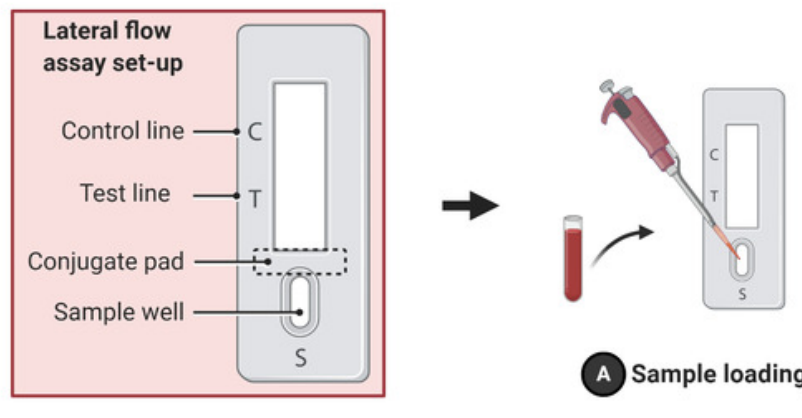

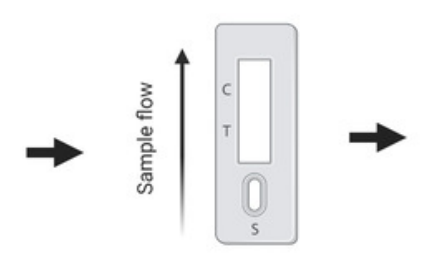

Sample incubation

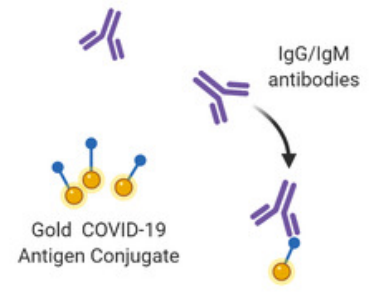

Antibody-antigen recognition
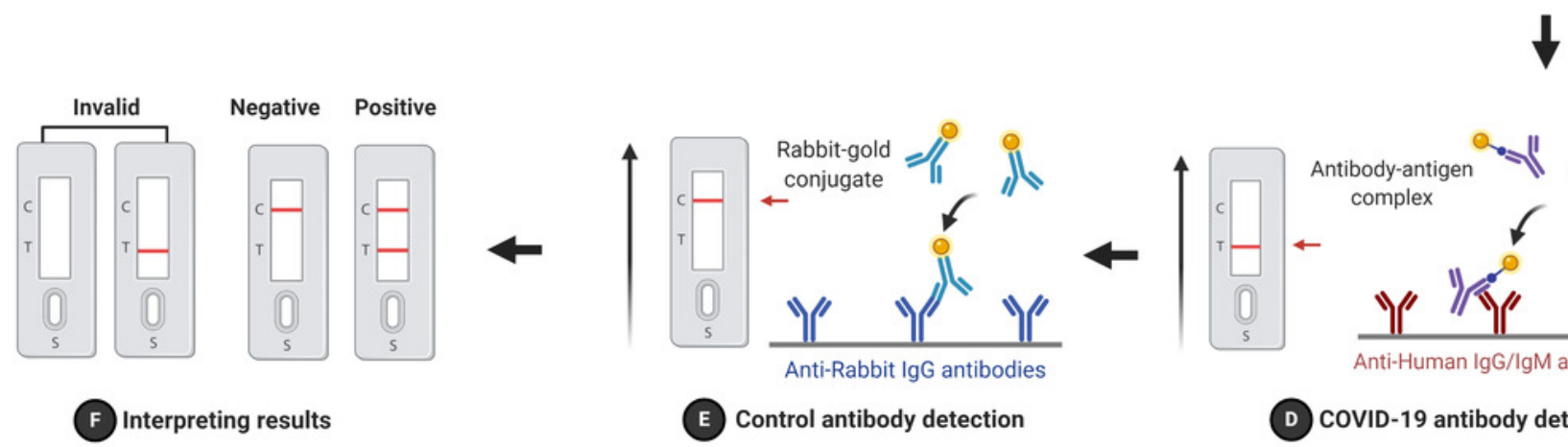

$$
1
$$
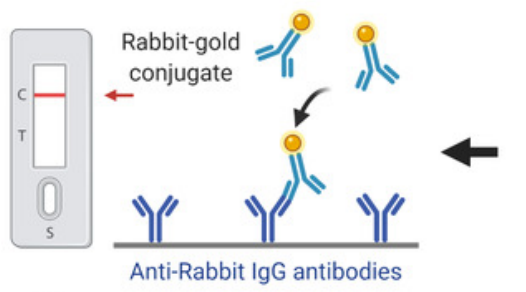

E Control antibody detection

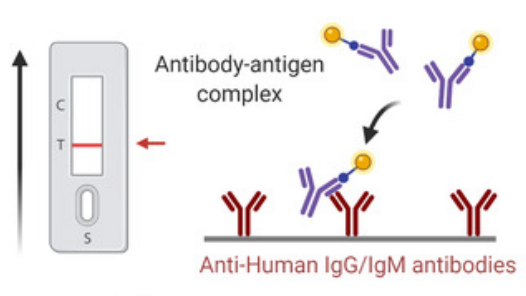

D COVID-19 antibody detection 


\section{Figure 4}

Schematic flowchart of indirect ELISA.

A coated SARS-CoV-2 protein (antigen) onto wells of ELISA plate (A) interacts with the first antibody (anti-SARS-CoV-2 antibody) that is in a patient's sample (B). (C) After adding a secondary antibody (a conjugated antibody), it recognizes and interacts with the first antibodies. The reaction is developed by adding a substrate (D) which is cleaved by the conjugated enzyme and changes the reaction color after incubation (E) and (F), respectively.

(G) Results are read by ELISA plate reader. The figure is created with BioRender.com.
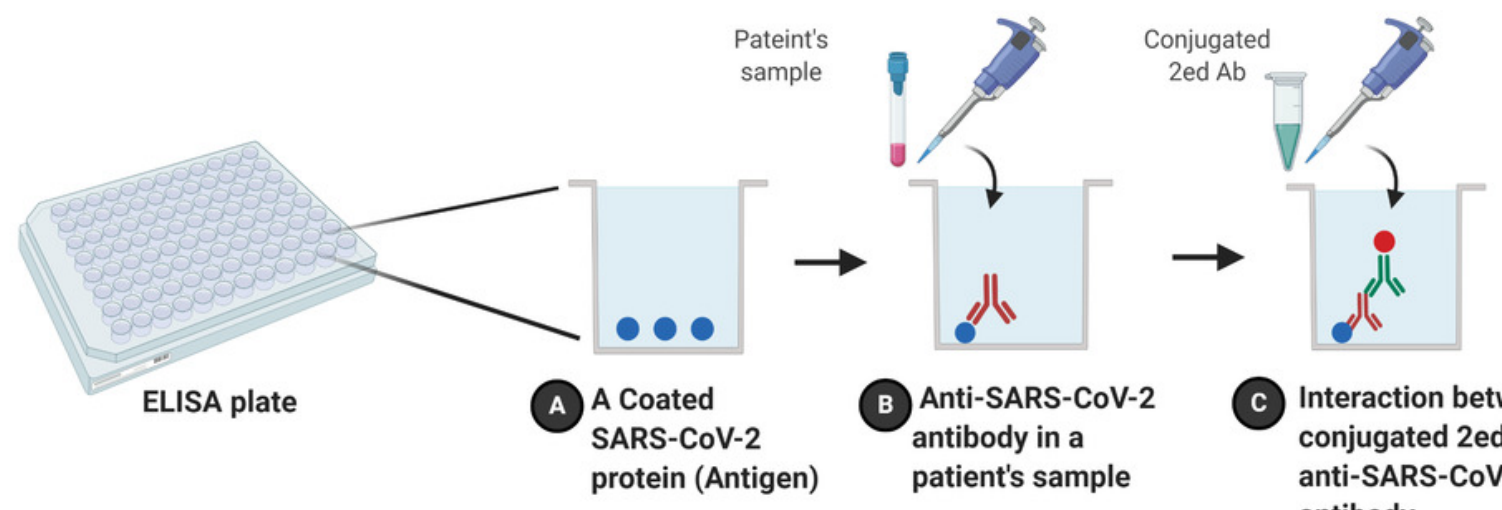

Anti-SARS-CoV-2 antibody in a patient's sample

C Interaction between the conjugated 2ed $\mathrm{Ab}$ and anti-SARS-CoV-2 antibody

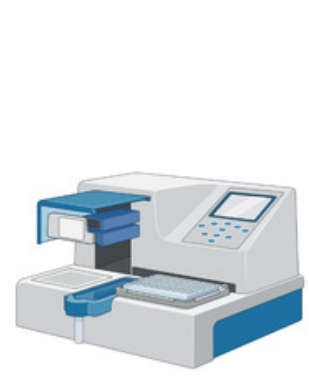

(G) ELISA plate reader
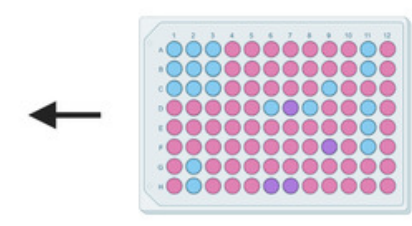

F) Incubation
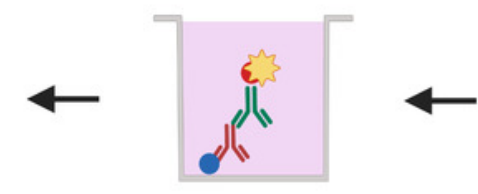

Substrate

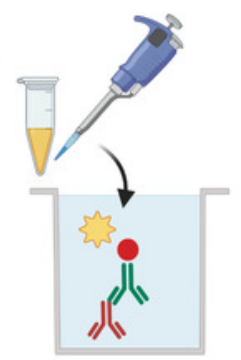

D Adding substrate

E Interaction between

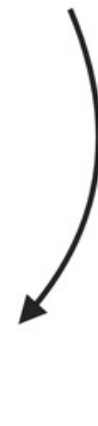
the substrate and conjugated 2ed Ab 


\section{Table 1 (on next page)}

Primers and probes that have been recommended by the U.S.CDC to detect SARS-CoV-2 by rRT-PCR 
1 Table 1:

2 Primers and probes that have been recommended by the U.S.CDC to detect SARS-CoV-2

3 by rRT-PCR

\begin{tabular}{|c|c|c|c|}
\hline $\begin{array}{l}\text { Gene } \\
\text { target }\end{array}$ & Description & Oligonucleotide Sequence $\left(5^{\prime}>3^{\prime}\right)$ & Label \\
\hline \multirow{3}{*}{$\begin{array}{l}\text { 2019- } \\
\text { nCoV_N1 }\end{array}$} & $\begin{array}{l}\text { 2019-nCoV_N1 Forward } \\
\text { Primer }\end{array}$ & 5'-GAC CCC AAA ATC AGC GAA AT-3' & None \\
\hline & $\begin{array}{l}\text { 2019-nCoV_N1 Reverse } \\
\text { Primer }\end{array}$ & $\begin{array}{l}\text { 5'-TCT GGT TAC TGC CAG TTG AAT CTG- } \\
\text { 3' }\end{array}$ & None \\
\hline & 2019-nCoV_N1 Probe & $\begin{array}{l}\text { 5'-FAM-ACC CCG CAT TAC GTT TGG TGG } \\
\text { ACC-BHQ1-3' }\end{array}$ & $\begin{array}{l}\text { FAM, } \\
\text { BHQ-1 }\end{array}$ \\
\hline \multirow{3}{*}{$\begin{array}{l}\text { 2019- } \\
\text { nCoV_N2 }\end{array}$} & $\begin{array}{l}\text { 2019-nCoV_N2 Forward } \\
\text { Primer }\end{array}$ & 5'-TTA CAA ACA TTG GCC GCA AA-3' & None \\
\hline & $\begin{array}{l}\text { 2019-nCoV_N2 Reverse } \\
\text { Primer }\end{array}$ & 5'-GCG CGA CAT TCC GAA GAA-3' & None \\
\hline & 2019-nCoV_N2 Probe & $\begin{array}{l}\text { 5'-FAM-ACA ATT TGC CCC CAG CGC TTC } \\
\text { AG-BHQ1-3' }\end{array}$ & $\begin{array}{l}\text { FAM, } \\
\text { BHQ-1 }\end{array}$ \\
\hline \multirow{3}{*}{ RNAse P } & $\begin{array}{l}\text { RNAse P Forward } \\
\text { Primer }\end{array}$ & 5'-AGA TTT GGA CCT GCG AGC G-3' & None \\
\hline & $\begin{array}{l}\text { RNAse P Reverse } \\
\text { Primer }\end{array}$ & 5'-GAG CGG CTG TCT CCA CAA GT-3' & None \\
\hline & RNAse P Probe & $\begin{array}{l}\text { 5'-FAM - TTC TGA CCT GAA GGC TCT } \\
\text { GCG CG - BHQ-1-3' }\end{array}$ & $\begin{array}{l}\text { FAM, } \\
\text { BHQ-1 }\end{array}$ \\
\hline
\end{tabular}

4

5

6 
Table 2 (on next page)

Expected results and their interpretations of rRT-PCR method for COVID-19 specimens 
1

2 Table 2:

3 Expected results and their interpretations of rRT-PCR method for COVID-19 specimens 4

\begin{tabular}{|c|c|c|c|}
\hline 2019nCoV-N1 & 2019nCoV-N2 & RNaseP & Result (SARS-CoV-2) \\
\hline+ & + & $+/-$ & Positive \\
\hline \multicolumn{2}{|c|}{$\begin{array}{c}\text { If only } 1 \text { of the } 2 \text { targets } \\
\text { is positive }\end{array}$} & $+/-$ & In conclusive \\
\hline - & - & + & Negative \\
\hline- & - & - & Invalid \\
\hline
\end{tabular}


Table 3 (on next page)

Expected results and their interpretations of SARS-CoV-2 DETECTR method for COVID-19 specimens 
1

2

3 Table 3:

4 Expected results and their interpretations of SARS-CoV-2 DETECTR method for COVID-

519 specimens

6

\begin{tabular}{|c|c|c|c|}
\hline N gene & E gene & RNaseP & Result (SARS-CoV-2) \\
\hline+ & + & $+/-$ & Positive \\
\hline+ & - & $+/-$ & Indeterminate \\
\hline- & + & $+/-$ & Indeterminate \\
\hline- & - & + & Negative \\
\hline- & - & - & Invalid \\
\hline
\end{tabular}

11

12

13

14

15 
Table 4 (on next page)

Comparison between molecular and serological methods for detecting COVID-19 virus 
1

2 Table 4:

3 Comparison between molecular and serological methods for detecting COVID-19 virus

4

\begin{tabular}{|l|c|c|c|c|c|}
\hline & \multicolumn{3}{c}{ Molecular Methods } & \multicolumn{2}{c|}{ Serological Methods } \\
\hline Technique based & rRT-PCR & Isothermal amplification & CRISPR-Cas12 & LFA & ELISA \\
\hline Sample & RNA & RNA & RNA & Ag or Ab & Ag or Ab \\
\hline Accuracy & High & High/Moderate & High & Low & Moderate \\
\hline Time* & Hours & Minutes & Minutes & Minutes & Hours \\
\hline Professional skills need & Yes & Yes & YES/ No & No & Yes \\
\hline POCT & No & Yes/ No & Yes/No & Yes & No \\
\hline Availability & Limited & Limited & Limited & Available & Available \\
\hline Cost & Very high & High & Average & Low & Average \\
\hline High throughput & Yes & No & No & No & Yes \\
\hline
\end{tabular}

5

$6 *$ Time that is required for running the test without preparation time.

7 